\title{
DINAMIKA FORMULASI AKAD TERHADAP PENGELOLAAN DANA HAJI DI INDONESIA
}

\author{
Maizul Imran \\ MUI Kabupaten Agam, maizulim91@gmail.com \\ Rio Satria \\ Pengadilan Agama Muaro Bungo, riosatria@gmail.com
}

Diterima: 5 Agustus $2018 \quad$ Direvisi:11 Oktober 2018 Diterbitkan: 30 Desember 2018

\begin{abstract}
The development of a hajj fund that is so great has the potential to be used in supporting the implementation of a better quality Haij through effective, efficient, transparent, accountable, and in accordance with the provisions of legislation. The strategy that has been taken by the Ministry of Religion to optimize the management of the Haij fund so that its benefits can be used to improve the quality of Haij implementation is by developing these funds through investment. But in fact, the dynamics that occur are in the BPIH deposit. When the funds are managed which constitute funds deposited by prospective pilgrims to the government (Ministry of Religion or BPKH) to finance the implementation of their pilgrimage, problems arise regarding the appropriate contract formulation to be used, whether wakalah contract, mudlarabah (profit sharing), or altogether no longer need a contract, because the government acts as a statutory power for prospective pilgrims, as consideration of the decision of the Constitutional Court (MK).
\end{abstract}

Keywords: Dinamika Formulasi Akad, Pengelolaan Dana Haji.

\begin{abstract}
Abstrak
Pengembangan dana haji yang begitu besar berpotensi untuk digunakan dalam mendukung penyelenggaraan ibadah haji yang lebih berkualitas melalui pengelolaan keuangan haji yang efektif, efisien, transparan, akuntabel, dan sesuai dengan ketentuan peraturan perundang-undangan. Strategi yang telab ditempub oleh Kementerian Agama untuk mengoptimalkan pengelolaan dana baji agar manfaatnya bisa digunakan bagi peningkatan kualitas penyelenggaraan ibadab haji adalah dengan cara mengembangkan dana tersebut melalui investasi. Namun secara faktual, dinamika yang terjadi terdapat pada setoran BPIH. Ketika dana tersebut dikelola yang merupakan dana titipan calon jemaah baji kepada pemerintah (Kementerian Agama atau BPKH) untuk membiayai penyelenggaraan ibadah baji mereka, maka timbul persoalan tentang formulasi akad yang tepat untuk digunakan, apakah akad wakalah, mudlarabah (bagi hasil), atau sama sekali tidak. lagi membutubkan akad, karena pemerintah bertindak sebagai kuasa menurut undang-undang bagi para calon jemaah haji, sebagaimana pertimbangan putusan Mabkamah Konstitusi (MK).
\end{abstract}

Kata kunci: Dinamika Formulasi Akad, Pengelolaan Dana Haji.

\section{PENDAHULUAN}

Sebelum Undang-Undang Nomor 34 Tahun 2014 Tentang Pengelolaan Keuangan Haji (selanjutnya disebut UU PKH) diundangkan, Pasal 47 Undang-Undang Nomor 13 Tahun 2008 Tentang Penyelenggaraan Ibadah Haji (selanjutnya disebut UU PIH) telah membuka peluang agar Dana Abadi Umat (DAU) ${ }^{1}$ dikelola dan

${ }^{1}$ Dana Abadi Umat (DAU) adalah sejumlah dana yang sebelum berlakunya Undang-Undang ini diperoleh dari hasil pengembangan DAU dan/atau sisa dikembangkan secara lebih berdaya guna serta berhasil guna untuk kemaslahatan umat Islam. ${ }^{2}$

biaya operasional penyelenggaraan ibadah haji serta sumber lain yang halal dan tidak mengikat sesuai dengan ketentuan peraturan perundang-undangan. Lihat, Pemerintah Republik Indonesia, Pasal 1 ayat (3), Undang-Undang No.34 tahun 2014 tentang Pengelolaan Keuangan Haji dan lihat juga, Pasal 1 ayat (17), UndangUndang Nomor 13 Tabun 2008 Tentang Penyelenggaraan Ibadah Haji.

${ }^{2}$ Guna melakukan pengelolaan Dana Abadi Umat (DAU) secara berdaya guna dan berhasil guna, maka berdasarkan Keputusan Presiden Nomor 22 Tahun 2001, dibenuk Badan Pengelola Dana Abadi Umat (BP-DAU). DAU dikelola untuk kemaslahatan 
Selain melakukan pengelolaan DAU berdasarkan UU PIH, Kementerian Agama juga telah mengelola dan mengembangkan BPIH berdasarkan Peraturan Menteri Agama Republik Indonesia Nomor 23 Tahun 2011 Tentang Pengelolaan Biaya Penyelenggaraan Ibadah Haji. Pengelolaan BPIH dilakukan untuk memperoleh manfaat dari dana tersebut berdasarkan asas: ${ }^{3}$ 1) Syariat Islam; 2) Manfaat; 3) Keadilan; 4) Profesional; dan 5) Akuntabel.

\section{METODE PENELITIAN}

Metode penelitian yang digunakan dalam tulisan ini adalah metode dekriptif analitis, maksudnya menggambarkan gagasan dan/atau gerakan yang terjadi secara faktual. dengan teknik pengumpulan data melalui pengamatan langsung dan kepustakaan. Kepustakaan menggunakan buku, majalah, dan artikel online dari media internet yang memiliki relevansi yang dianggap penting serta mengambil intisari dari bacaan tersebut yang sesuai dengan informasi yang berkaitan dengan permasalahan yang dibahas dalam makalah ini. Adapun analisis yang digunakan adalah analisis kualitatif, yakni suatu analisis yang tidak membutuhkan angka-angka. ${ }^{4}$

\section{DISKURSUS PENGELOLAAN DANA HAJI DI INDONESIA}

Ibadah haji memiliki perbedaan dengan beberapa ibadah lain yang termasuk dalam rukun Islam yaitu memerlukan biaya yang relatif banyak mencapai puluhan juta rupiah. Nilai nominal sebesar itu bagi masyarakat Indonesia bisa dikatakan cukup mahal,

umat dalam bidang: a. pendidikan dan dakwah, b. kesehatan, c. sosial, d. ekonomi, e. pembangunan sarana dan prasarana ibadah, dan f. penyelenggaraan ibadah haji. Lihat, Pemerintah Republik Indonesia, Keputusan Presiden (Kepres) Nomor 22 Tabun 2001.

3 Kementerian Agama, Pasal 2, Peraturan Menteri Agama Nomor 23 Tabun 2011 Tentang Pengelolaan Biaya Penyelenggaraan Ibadab Haji.

4 Aan Satori, Djam'an dan Komariyah, Metodologi Penulisan Kualitatif. (Bandung: Alfabeta, 2009), h. 34 . mayoritas penduduk Indonesia tingkat kesejahteraannya berada dibawah garis kemiskinan. Bagi mereka yang berkecukupan secara finansial, naik haji tentu tidak menjadi masalah. Namun bagi mereka yang tidak memilki cukup uang maka harus berusaha sekuat tenaga bekerja dan menabung untuk bisa menunaikan ibadah haji. Banyak umat muslim menabung di bank selama bertahuntahun atau melakukan usaha lainnya seperti menjual perhiasan atau hewan ternak supaya dapat melaksanakan impian banyak kaum muslim didunia ini, yakni beribadah haji ke tanah suci Mekkah. Walaupun mayoritas penduduk Indonesia tingkat kemampuan ekonominya rendah, namun setiap tahun kita menyaksikan ratusan ribu umat Islam Indonesia pergi menunaikan ibadah haji ke Arab Saudi setiap tahunnya. ${ }^{5}$

Animo masyarakat muslim di Indonesia untuk melaksanakan ibadah haji ke tanah suci Mekkah adalah yang paling tinggi dibandingkan dengan negara-negara lain didunia, setiap tahunnya terjadi peningkatan, sekalipun pemerintah melalui Peraturan Menteri Agama No 6 Tahun 2010 telah menaikkan setoran awal bagi jama'ah haji reguler yang semula sebesar Rp 20 Juta menjadi Rp 25 Juta, dan haji khusus dari USD 3000 menjadi USD 4000. Sampai tanggal 7 Juni 2011 saja jumlah daftar tunggu (waiting list) jamaah haji Indonesia mencapai angka 1.420.915, terdiri dari 1.377.414 orang jamaah haji regular dan 43.501 orang jamaah haji khusus.

Setelah UU PKH diundangkan, peluang tersebut lebih dibuka lebar, sebagaimana dalam Pasal 46 Undang-undang tersebut, keuangan haji ${ }^{6}$ wajib dikelola di Bank Umum Syariah

${ }^{5}$ Riko Nazri, Optimalisasi Pengelolaan Dana Haji Untuk Kesejabteraan Jamaah Haji Indonesia (Sebuah Gagasan), (jurnal Khazanah, FIAI UII, vol. 6, no. 1 Juni 2013), h. 13-14.

${ }^{6}$ Keuangan haji adalah adalah semua hak dan kewajiban Pemerintah yang dapat dinilai dengan uang terkait dengan penyelenggaraan ibadah haji serta semua 
dan/atau Unit Usaha Syariah atau ditempatkan dan/atau diinvestasikan sesuai dengan prinsip syariah dengan mempertimbangkan aspek keamanan, kehati-hatian, nilai manfaaat, dan likuiditas. $^{7}$

Saat ini aliran kas setoran awal dana haji (BPIH) yang dibayarkan oleh jama'ah untuk memperoleh nomor antrian haji hanya diinvestasikan ke instrument-instrumen keuangan tabungan deposito di Bank Indonesia maupun dibeberapa Bank Penerima Setoran (BPS) dan diinvestasikan pula ke Surat Beharga Syariah Negara (SBSN) atau sukuk yang setiap tahunnya memperoleh laba sebesar 1,5 triliun atau sebesar 7,5\%.

Peluang investasi dana haji ${ }^{8}$ dibuka lebar karena jumlah warga negara Indonesia yang mendaftar untuk menunaikan ibadah haji terus meningkat, sedangkan kuota haji terbatas', sehingga jumlah jemaah haji yang masuk daftar tunggu tunggu (waitinglist) terus meningkat. Hingga akhir Juli 2017, waiting list jemaah haji

kekayaan dalam bentuk uang atau barang yang dapat dinilai dengan uang sebagai akibat pelaksanaan hak dan kewajiban tersebut, baik yang bersumber dari jemaah haji maupun sumber lain yang sah dan tidak mengikat. Lihat, Pasal 1 ayat (1), UU PKH. UU PKH.

7 Pemerintah Republik Indonesia, Pasal 46,

8 Dana Haji adalah dana setoran biaya penyelenggaraan ibadah haji, dana efisiensi penyelenggaraan haji, dana abadi umat, serta nilai manfaat yang dikuasai oleh negara dalam rangka penyelenggaraan ibadah haji dan pelaksanaan program kegiatan untuk kemaslahatan umat Islam. Lihat, Pasal 1 ayat (2), UU PKH.

${ }^{9}$ Lihat, Kementerian Agama, Keputusan Menteri Agama Nomor 20 Tabun 2008 Tentang Penetapan Kuota Haji Tabun 1429 H. Kementerian Agama, Keputusan Menteri Agama Nomor 46 Tabun 2009 Tentang Penetapan Kuota Haji Tabun 1430 H. Kementerian Agama, Keputusan Menteri Agama Nomor 29 Tabun 2011 Tentang Penetapan Kuota Haji Tabun 1432 H. Kementerian Agama, Keputusan Menteri Agama Nomor 58 Tabun 2013 Tentang Penetapan Kuota Haji Tabun 1434 H / 2013 M. Kementerian Agama, Keputusan Menteri Agama Nomor 64 Tabun 2014 Tentang Penetapan Kuota Haji Tabun 1435 H / 2014 M. Kementerian Agama, Keputusan Menteri Agama Nomor 210 Tabun 2016 Tentang Penetapan Kuota Haji Tabun 1437 H / 2017 M. Kementerian Agama, Keputusan Menteri Agama Nomor 75 Tahun 2017 Tentang Penetapan Kuota Haji Tabun 1438 H / $2017 \mathrm{M}$. reguler tercatat sebesar 3.305.207 orang dan haji khusus sejumlah 104.941 orang. ${ }^{10}$

Untuk mendapatkan daftar tunggu (waitinglist) tersebut, setiap calon jemaah haji harus melunasi terlebih dahulu setoran awal BPIH sejumlah Rp25.000.000,00 (dua puluh lima juta rupiah). Oleh karena itu, peningkatan daftar tunggu calon jemaah haji berkorelasi positif dengan peningkatan akumulasi dana haji yang terkumpul di rekening haji Kementerian Agama. Dalam lima tahun terakhir, akumulasi dana haji terus bertambah degan rata-rata peningkatan sebesar 10,19\% setiap tahun. Berikut ini uraian akumulasi dana haji yang terkumpul dalam rentang waktu lima tahun terakhir, hingga bulan Juni 2017: ${ }^{11}$

\begin{tabular}{|l|c|c|}
\hline No & Tahun & $\begin{array}{c}\text { Dana Haji } \\
\text { (Triliun } \\
\text { rupiah) }\end{array}$ \\
\hline 01 & 2013 & 67,98 \\
\hline 02 & 2014 & 69,86 \\
\hline 03 & 2015 & 78,48 \\
\hline 04 & 2016 & 95,2 \\
\hline 05 & Juni 2017 & 99,34 \\
\hline
\end{tabular}

Tabel 1: Dana Haji Tahun 2011 Sampai Dengan Tahun 2015

Pengembangan dana haji yang begitu besar berpotensi untuk digunakan dalam mendukung penyelenggaraan ibadah haji yang lebih berkualitas melalui pengelolaan keuangan

${ }^{10}$ Siaran Pers Bersama Kemkominfo, Kemenag, Kementerian PPN/Bappenas, dan MUI, Manfaat Investasi Dana Haji Untuk Umat, 05 Agustus 2017.

${ }^{11}$ Kementerian Agama, Laporan Keuangan Haji Tabun 2011 Sampai Dengan Tabun 2015. Lihat juga, Humas Sekretariat Kabinet Republik Indonesia, Jumlabnya Mendekati 100 Triliun, Menag: Selurub Dana Haji Akan Diserabkan Pada BPKH, http://setkab.go.id, diakses pada tanggal 18 Januari 2018. Lihat juga, Siaran Pers Bersama Kemkominfo, Kemenag, Kementerian PPN/Bappenas, dan MUI, Manfaat Investasi Dana Haji Untuk Umat, 05 Agustus 2017. 
haji yang efektif, efisien, transparan, akuntabel, dan sesuai dengan ketentuan peraturan perundang-undangan. ${ }^{12}$ Strategi yang telah ditempuh oleh Kementerian Agama untuk mengoptimalkan pengelolaan dana haji agar manfaatnya bisa digunakan bagi peningkatan kualitas penyelenggaraan ibadah haji adalah dengan cara mengembangkan dana tersebut melalui investasi.

Pada tahun 2009, dengan semangat menciptakan manfaat bagi umat, Menteri Keuangan Sri Mulyani dan Menteri Agama Muhammad Maftuh Basyuni telah melakukan penandatanganan nota kesepahaman $(\mathrm{MoU})$ mengenai mekanisme investasi dana haji dalam Surat Berharga Syariah Negara (SBSN) atau Sukuk Negara dengan cara private placement ${ }^{13}$. Kesepakatan tersebut kemudian dilanjutkan pada tahun 2013 oleh Menteri Keuangan Chatib Basri dan Menteri Agama Suryadharma Ali dengan menandatangani kesepakatan peruntukan dana haji bagi pembiayaan APBN, temasuk proyek Kementerian Agama untuk penyelenggaraan haji melalui SBSN PBS (Project Based Sukuk). ${ }^{14}$ Hingga tanggal 12 Januari 2017, Direktorat Jenderal Pengelolaan Pembiayaan dan Risiko Kementerian Keuangan telah mencatat bahwa outstanding SBSN atau Sukuk Dana Haji Indonesia (SDHI) adalah sebesar Rp36,7 triliun. ${ }^{15}$ UU PKH.

${ }^{12}$ Pemerintah Republik Indonesia, Konsideran

${ }^{13}$ Private Placement adalah penempatan sejumlah modal tertentu dalam suatu perusahaan melalui pemebelian asset/sekuritas dimana transaksi tersebut terjadi pada pasar negosiasi. Transaksi ini dilakukan atas dasar kesepakatan yang dicapai antara emiten dengan investor, sedangkan sekuritas hanya sebagai perantara saja supaya tidak terjadi gagal serah atau gagal bayar. Lihat, Unnes Stock Exchange Study Forum (UNNSAF), Private Placement, https://unssaf.or.id, diakses pada tanggal 15 Januari 2018.

${ }^{14}$ Siaran Pers Bersama Kemkominfo, Kemenag, Kementerian PPN/Bappenas, dan MUI, Manfaat Investasi Dana Haji Untuk Umat, (Forum Merdeka Barat 9), 05 Agustus 2017.

${ }^{15}$ Siaran Pers Bersama Kemkominfo, Kemenag, Kementerian PPN/Bappenas, dan MUI,
Sebagaimana telah dikemukakan di atas, asas utama melakukan investasi dana haji adalah kesesuaian dengan prinsip syariah. Dengan demikian, investasi tersebut harus dilakukan atas dasar suka sama suka atau kerelaan (al-taradli), keadilan (al-adalab), dan tidak saling merugikan (laa dlarara wa laa diraara). Investasi dana haji tidak boleh mengandung hal-hal yang haram, seperti ketidakpastian atau ketidakjelasan (gharar), perjudian (maysir), bunga (riba), penganiayaan (zhulm), suap (risywah), maksiat, dan objek haram. $^{16}$

Kerelaan (al-taradli) masing-masing pihak melakukan investasi diucapkan atau dituangkan dalam bentuk akad. Akad berisikan persetujuan kedua belah pihak memenuhi hak dan kewajiban masing-masing. Akad yang sah tidak boleh mengandung unsur khilaf (ghalath), dilakukan di bawah paksaan (ikrab), tipuan (taghrir), dan penyamaran (ghubn). Akad tersebut harus memuat ketentuan sebagai berikut: ${ }^{17}$

1. Kesepakatan mengikatkan diri;

2. Kecakapan untuk membuat suatu perikatan;

3. Terhadap suatu hal tertentu;

4. Suatu sebab yang halal menurut syariat Islam.

Persyaratan yang pertama dan kedua, kesepakatan dan kecakapan, disebut persyaratan subjektif karena berkaitan dengan subjek yang membuat atau mengadakan akad.

Manfaat Investasi Dana Haji Untuk Umat, (Forum Merdeka Barat 9), 05 Agustus 2017.

${ }^{16}$ Dewan Syariah Nasional Majelis Ulama Indonesia, Fatwa Dewan Syariah Nasional Majelis Ulama Indonesia (DSN-MUI) Nomor 20/DSN-MUI/IV/2001 Tentang Pedoman Pelaksanaan Investasi Untuk Reksadana. Lihat juga, Otoritas Jasa Keuangan (OJK), Pasal 53 huruf (b), Peraturan OJK Nomor 69 /POJK.05/2016 Tentang Penyelenggaraan Usaha Perusabaan Asuransi, Perusahaan Asuransi Syariah, Perusabaan Reasuransi, Dan Perusahaan Reasuransi Syariah.

${ }^{17}$ Mahkamah Agung RI, Pasal 29 (2), Peraturan Mabkamah Agung RI Nomor 2 Tabun 2008 Tentang ompilasi Hukum Ekonomi Syariah. Lihat juga, Pasal 1320, Kitab Undang-Undang Hukum Perdata. 
Sedangkan persyaratan ketiga dan keempat, suatu hal tertentu dan sebab yang halal, adalah persyaratan objektif, karena persyaratan tersebut berkaitan dengan objek akad atau perjanjian. Jika persyaratan subjektif tidak lengkap, maka akad tersebut dapat dibatalkan (vernietigbaarheid), selama akad belum diajukan pembatalan ke pengadilan, maka akad tersebut masih sah. Sedangkan jika persyaratan objektif yang tidak legkap, maka akad batal demi hukum (null and void), perjanjian dipandang tidak sah sejak pertama kali dibuat. ${ }^{18}$

Akad dalam pandangan hukum Islam juga mesti mengandung nilai keadilan (al-'adalab) serta tidak merugikan salah satu pihak (laa dlarara wa laa dliraara). Oleh karena itu, isi akad harus jelas, baik objek, sistem pembagian resiko dan keuntungan, pihak-pihak mendapatkan keuntungan ataupun menangung resiko secara proporsional, tidak melebihi hak ataupun kewajibannya, serta juga mengandung kejelasan tentang mekanisme penyelesaian sengketa.

Setoran BPIH dan/atau BPIH khusus, sebagai komponen utama dana haji, adalah dana titipan calon jemaah haji. Kementerian Agama (BPKH dalam UU PKH) menerima setoran tersebut melalui Bank Penerima Setoran BPIH (BPS BPIH) dalam kapasitas sebagai wakil yang sah dari calon jemaah haji. ${ }^{19}$ Ketentuan di atas sejalan dengan hasil ijtima Ulama Komisi Fatwa se-Indonesia IV di Cipasung, Jawa Barat pada tahun 2012, yang memutuskan bahwa setoran awal calon jemaah haji yang masuk daftar tunggu (waitinglist), secara syar'i adalah milik pendaftar (calon jemaah haji) tersebut. ${ }^{20}$

${ }^{18}$ Ridawan Khairandy, Hukum Kontrak Indonesia (Dalam Perspektif Perbandingan), (Yogyakarta: FH UII Press, 2013), h. 191-192.

${ }^{19}$ Pemerintah Republik Indonesia, Pasal 6 ayat (2) dan Pasal 7 ayat (1), UU PKH.

${ }^{20}$ Dana setoran haji yang ditampung dalam rekening Menteri Agama, adapun pendaftarnya masuk daftar tunggu (waitinglist), secara syar'i adalah milik pendaftar (calon jemaah haji). Oleh sebab itu, apabila yang bersangkutan meninggal atau ada halangan syar'i
Oleh karena pemerintah hanya bertindak sebagai wakil sah calon jemaah haji, maka pada saat mendaftar haji, para calon jemaah haji mengisi dan meneken formulir akad wakalah, calon jemaah haji selaku muwakkil memberikan kuasa kepada Kementerian Agama selaku wakil, untuk menerima dan mengelola dana setoran awal Biaya Penyelenggaraan Ibadah Haji (BPIH) sesuai dengan ketentuan perundang-undangan yang berlaku. Oleh karena itu, menurut Menteri Agama, Lukman Hakim Saifuddin, pemerintah, dalam hal ini $\mathrm{BPKH}$, mengemban amanat untuk mengelola dana haji tersebut, termasuk untuk menginvestasikannya, demi kebaikan umat secara keseluruhan, terutama peningkatan kesejahteraan jamaah haji Indonesia. ${ }^{21}$

Pemberlakukan UU PKH telah memberikan kewenangan kepada BPKH, selama ini Kementerian Agama, untuk mengelola dan mengembangkan dana haji. Maka, bagi pihak yang merasa hak konstitusionalnya telah dirugikan dengan pemberlakuan Undang-undang tersebut, mengajukan uji materi (judicial review) ke Mahkamah Konstitusi (MK). UU PKH telah digugat ke MK sebanyak dua kali, yakni

yang membuat calon jamaah haji yang bersangkutan gagal berangkat, maka dana setoran haji wajib dikembalikan kepada calon jama'ah haji atau ahli warisnya. Dana setoran haji calon jamaah yang termasuk daftar tunggu selayaknya di-tasharruf-kan untuk hal-hal yang produktif serta dikelola dengan mitigasi risiko yang tinggi. Oleh karena itu, atas nama pemilik, pemerintah disilakan men-tasharruf-kan dana tersebut pada sektor yang halal, yaitu sektor yang terhindar dari maisir, gharar, riba, dan lain-lain. Dana hasil tasharruf adalah milik calon jamaah haji yang termasuk dalam daftar tunggu, antara lain sebagai penambah dana simpanan calon jamaah haji atau pengurang biaya haji yang riil/nyata), sebagai pengelola, pemerintah (Kementerian Agama) berhak mendapatkan imbalan (ujrah) yang wajar/tidak berlebihan sebagaimana dijelaskan dalam hadits ibn Umar tentang hak pengelola wakaf. Lihat, Majelis Ulama Indonesia, Hasil Ijtima' Ulama IV Masail Fiqhiyab Mu'ashirah (Masalah Fiqh Kontemporer) Komisi B-2, tahun 2012.

${ }^{21}$ Siaran Pers Bersama Kemkominfo, Kemenag, Kementerian PPN/Bappenas, dan MUI, Manfaat Investasi Dana Haji Untuk Umat, (Forum Merdeka Barat 9), 05 Agustus 2017. 
perkara Nomor 12/PUU-XIII/2015 dan perkara Nomor 51/PUU-XV/2017. Kedua permohonan uji materi tersebut pada pokoknya mendalilkan bahwa pemberian mandat kepada BPKH untuk mengelola dana haji dan mengambil biaya operasional, termasuk belanja pegawai, dari nilai manfaat pengembangan dana tersebut telah merugikan hak konstitusional pemohon, sebagai salah satu calon jemaah haji, karena setoran dana uang muka BPIH adalah milik para calon jemaah haji. Sehingga dengan demikian, jika dana tersebut dikelola atau dimanfaatkan oleh $\mathrm{BPKH}$, tanpa seizin para calon jemaah haji, berarti telah menyalahi hak para calon jemaah haji. ${ }^{22}$

Kedua permohonan uji materi di atas telah ditolak oleh Mahkamah Konstitusi (MK). Di antara pokok pertimbangan hukum (legal reasoning) MK adalah ketika rakyat telah memilih wakil-wakilnya untuk duduk di pemerintahan, maka pada saat itu telah terbentuk kontrak antara rakyat dengan pemerintah. Oleh karena itu, ketika pemerintah menjalankan tugas pelayanan publik tidak lagi membutuhkan kontrak baru dengan rakyatnya, termasuk pengelolaan dana haji oleh BPKH, apalagi BPIH bukanlah berstatus sebagai tabungan haji, namun uang muka (down payment-DP) untuk booking seat antrian haji, meskipun dana tersebut masih berstatus milik para calon jemaah haji. ${ }^{23}$ Adapun tentang penggunaan nilai manfaat pengembangan dana haji untuk biaya operasional $\mathrm{BPKH}$, menurut $\mathrm{MK}$ tidak bertentangan dengan konstitusi, karena BPKH bertugas untuk mengelola dana haji, sehingga $\mathrm{BPKH}$ juga berhak untuk memperoleh biaya operasional dari nilai manfaat tersebut. ${ }^{24}$

\begin{tabular}{cccc}
\hline 22Mahkamah Konstitusi, & Putusan & Nomor \\
51/PUU-XV/2017, h. 14 & & \\
23 Mahkamah Konstitusi, & Putusan & Nomor \\
51/PUU-XV/2017, h. 72-74. & & \\
24Mahkamah Konstitusi, & Putusan & Nomor \\
12/PUU-XIII/2015, h. 90-91. & &
\end{tabular}

Ada perbedaan mendasar yang terlihat jika menghubungkan pertimbangan hukum Putusan MK di atas dengan keterangan resmi Kementerian Agama. Menurut keterangan resmi Kementerian Agama, pengelolaan dana haji menggunakan akad wakalah, sedangkan menurut MK, pengelolaan dana tersebut tidak lagi membutuhkan kontrak baru antara para calon jemaah haji dengan pemerintah, kegiatan tersebut bagian dari pelayanan publik.

Pengambilan nilai manfaat investasi dana haji oleh BPKH untuk biaya operasional, selama ini oleh Kementerian Agama, juga tidak sesuai dengan fatwa Dewan Syariah Nasional Majelis Ulama Indonesia (DSN-MUI) Nomor 52/DSN-MUI/III/2006 Tentang Akad Wakalah Bil Ujrah Pada Asuransi Syari'ah Dan Reasuransi Syari'ah. Meskipun fatwa tersebut dalam bidang asuransi, namun akad yang digunakan sama dengan akad dalam pengelolaan dana haji. Menurut fatwa tersebut, wakil tidak berhak memperoleh bagian dari hasil investasi, karena akad yang digunakan adalah akad wakalah.

Adapun objek investasi yang selama ini digunakan oleh Kementerian Agama untuk mengembangkan dana haji adalah berbagai objek investasi yang aman, menjanjikan nilai manfaat, serta memiliki likuiditas yang tinggi. Instrumen investasi yang digunakan adalah sebagai berikut: ${ }^{25}$

1. Membeli Surat Berharga Syariah Negara (SBSN);

2. Membeli Surat Utang Negara; dan/atau

3. Menempatkan dalam bentuk deposito berjangka.

Dari ketiga instrumen investasi yang dipilih oleh Kementerian Agama untuk mengembangkan dana haji, investasi pada Surat Berharga Syariah Negara (SBSN) atau Sukuk Negara jelas memenuhi kriteria prinsip

${ }^{25}$ Kementerian Agama, Pasal 11 ayat (2), Peraturan Menteri Agama Nomor 23 Tabun 2011 Tentang Pengelolaan Biaya Penyelenggaraan Ibadah Haji. 
syariah, karena Sukuk Negara diterbitkan berdasarkan akad yang tidak bertentangan dengan prinsip syariah, seperti akad ijarah, mudarabah, musyarakah, istishna', dan akad-akad lain yang sesuai dengan prinsip syariah. ${ }^{26}$

Pilihan instrumen investasi dana haji melalui pembelian Surat Utang Negara (SUN) jelas mengandung unsur riba (bunga), karena SUN adalah surat berharga berupa pengakuan utang dalam mata uang Rupiah maupun valuta asing yang dijamin pembayaran bunga dan pokoknya oleh Negara Republik Indonesia, sesuai dengan masa berlakunya. ${ }^{27}$ Hasil audit per 2016 menunjukkan bahwa pada tanggal 31 Desember 2016, jumlah dana haji yang diinvestasikan melalui Surat Utang Negara (SUN) adalah sebesar Rp136 miliar. ${ }^{28}$

Instrumen investasi yang ketiga yang digunakan oleh Kementerian Agama adalah menempatkan dana haji pada deposito bank secara berjangka. Adapun kriteria bank yang dipilih adalah sebagai berikut: ${ }^{29}$

1. Sehat menurut Bank Indonesia;

2. Menjadi anggota Lembaga Penjamin Simpanan; dan

3. Memiliki kemampuan untuk membayar kembali semua kewajiban pada saat jatuh tempo;

Berdasarkan hasil audit per 2016, deposito berjangka adalah instrumen keuangan yang menjadi penempatan terbesar dana haji,

\footnotetext{
${ }^{26}$ Pemerintah Republik Indonesia, Pasal 3, Undang-Undang Nomor 19 Tabun 2008 Tentang Surat Berharga Syariah Negara.

${ }^{27}$ Direktorat Surat Utang Negara Direktorat Jenderal Pengelolaan Utang Kementerian Keuangan Republik Indonesia, Mengenal Surat Utang Negara, leaflet.

${ }^{28}$ Humas Sekretariat Kabinet Republik Indonesia, Jumlahnya Mendekati 100 Triliun, Menag: Selurub Dana Haji Akan Diserabkan Pada BPKH, http://setkab.go.id, diakses pada tanggal 18 Januari 2018

${ }^{29}$ Kementerian Agama, Pasal 11 ayat (3), Peraturan Menteri Agama Nomor 23 Tahun 2011 Tentang Pengelolaan Biaya Penyelenggaraan Ibadab Haji.
}

dibandingkan instrumen lainnya, yakni sebesar Rp54,57 triliun. ${ }^{30}$

Investasi melalui deposito, tidak seluruhnya memenuhi kriteria prinsip syariah, sehingga Dewan Syariah Nasional Majelis Ulama Indonesia (DSN-MUI) menerbitkan fatwa Nomor 03/DSN-MUI/IV/2000 Tentang Deposito ${ }^{31}$, sebagai pedoman tentang bentuk-bentuk mu'amalah syariyah dalam pelaksanaan deposito pada bank syari'ah. Deposito yang dibenarkan menurut prinsip syariat Islam adalah deposito berdasarkan prinsip mudarabah. ${ }^{32}$

Jika diperhatikan kriteria deposito yang dimaksud di dalam Peraturan Menteri Agama Republik Indonesia Nomor 23 Tahun 2011 Tentang Pengelolaan Biaya Penyelenggaraan Ibadah Haji, ternyata hanya menekankan tentang kesehatan bank, sehingga ada jaminan, jika telah jatuh tempo, semua kewajiban dapat dibayarkan oleh bank tersebut. Sedangkan prinsip syariah tidak dijadikan kriteria atau ukuran dalam memilih bank sebagai penempatan deposito dana haji.

Penempatan dana haji pada instrumen investasi yang bertentangan dengan prinsip syariah tentu juga bertentangan dengan tujuan utama dana tersebut disetorkan oleh calon jemaah haji, yakni untuk menjalankan rukun Islam kelima. Jika hasil investasi berbasis bunga digabungan dengan dana haji secara umum, maka akan menyebabkan

${ }^{30}$ Humas Sekretariat Kabinet Republik Indonesia, Jumlabnya Mendekati 100 Triliun, Menag: Selurub Dana Haji Akan Diserabkan Pada BPKH,

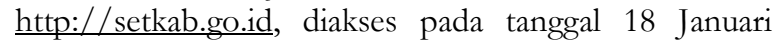
2018.

${ }^{31}$ Deposito adalah simpanan dana berjangka yang penarikannya hanya dapat dilakukan pada waktu tertentu berdasarkan perjanjian nasabah penyimpan dengan bank. Lihat, Dewan Syariah Nasional Majelis Ulama Indonesia, Fatwa Dewan Syariah Nasional Majelis Ulama Indonesia (DSN-MUI) Nomor 03/DSNMUI/IV/2000 Tentang Deposito.

${ }^{32}$ Dewan Syariah Nasional Majelis Ulama Indonesia, Fatwa Dewan Syariah Nasional Majelis Ulama Indonesia (DSN-MUI) Nomor 03/DSN-MUI/IV/2000 Tentang Deposito. 
tercampurnya pendapatan halal dengan pendapatan non-hal. Dalam hal demikian, seharusnya pendapatan halal terlebih dahulu dipisahkan dari pendapatan yang tidak halal (al-tafriq al-halal wa al-haram ${ }^{33}$ ).

Pada momen pelantikan anggota Badan Pengelola Keuangan Haji (selanjutnya disebut BPKH $)^{34}$, Presiden Jokowi juga menyampaikan agar dana haji dikelola dan diinvestasikan ke tempat-tempat yang memberikan keuntungan yang baik dan tidak beresiko tinggi, di antaranya untuk membangun infrastruktur. Hasil keuntungan investasi tersebut bisa digunakan untuk mensubsidi ongkos dan biaya haji, sehingga lebih terjangkau oleh masyarakat, sebagaimana yang telah diterapkan di negara lain, seperti Malaysia. ${ }^{35}$ Namun gagasan Presiden tersebut di atas menjadi kontroversi hingga saat ini. Bagi yang pihak yang menentang, menilai bahwa dana haji tidak bisa diinvestasikan ke sektor infrastruktur dengan berbagai argumentasi, mulai dari permasalahan akad, sebagaimana perdebatan di atas, pembagian imbal hasil, dan hingga investasi tersebut dinilai melanggar undangundang. ${ }^{36}$

${ }^{33}$ Tiga langkah yang ditawarkan oleh K.H. Ma'ruf Amin dalam mendobrak kejumudan berfikir hukum ekonomi syariah adalah, pertama, tahqiq almanath, yakni analisis untuk mengetahui adanya alasan hukum ('illah) dalam suatu kasus setelah 'illah tersebut diketahui melalui nash, ijma', atau istinbath. Kedua, i'adatu al-nazhar (telaah ulang), yakni telaah ulang terhadap pendapat ulama-ulama terdahulu yang untuk saat ini sudah tidak relevan lagi untuk digunakan. Dan ketiga, tafriq al-halal min al-haram (memisahkan yang halal dari yang haram), yakni memisahkan kekayaan yang halal dari kekayaan yang bersumber dari pendapatan yang haram. Lihat M. Ath Mudzhar, EsaiEsai Sejarah Sosial Hukum Islam, (Yogyakarta: Pustaka Pelajar,2014), Cet. Ke-1, h. 84-90.

${ }^{34}$ Badan Pengelola Keuangan Haji (BPKH) adalah lembaga yang melakukan pengelolaan Keuangan Haji. Lihat Pasal 1 ayat (4), UU PKH.

${ }^{35}$ Ihsanudin, Jokowi Ingin Dana Haji Diinvestasikan Untuk Infrastruktur, https://kompas.com, diakses pada tanggal 15 Januari 2018.

${ }^{36}$ Ahmad Muntaha A.M., Hukum Investasi Dana Haji, aswajamuda.com, diakses pada tanggal 07 Januari 2018.
Keinginan Presiden Jokowi untuk menginvestasikan dana haji pada sektor infrastruktur dinilai bertentangan dengan peraturan perundang-undangan, karena menurut Pasal 48 UU PKH, penempatan dan/atau investasi Keuangan Haji dapat dilakukan dalam bentuk produk perbankan, surat berharga, emas, investasi langsung dan investasi lainnya. Berdasarkan praktek pengelolaan dana haji selama ini, investasi hanya dilakukan sebatas untuk kepentingan pendidikan dan dakwah, kesehatan, sosial, ekonomi, pembangunan sarana dan prasarana ibadah, dan penyelenggaraan ibadah haji. Meskipun demikian, dalam Pasal 24 huruf (a) dan (b) UU PKH, hanya disebutkan bahwa Keuangan Haji diinvestasikan sesuai dengan prinsip syariah, kehati-hatian, keamanan, dan nilai manfaat, tanpa menunjuk atau menentukan objek investasi yang dibenarkan secara khusus. ${ }^{37}$

\section{PERBANDINGANNYA DENGAN PENGELOLAAN DANA HAJI DI MALAYSIA}

Meskipun dana haji telah dikelola sejak lama oleh Kementerian Agama, namun berdasarkan data 5 (lima) tahun terakhir, BPIH Indonesia terus mengalami fluktuasi, seiiring dengan nilai tukar Rupiah (Rp) terhadap Dolar Amerika (USD). Kondisi tersebut berbeda dengan Malaysia, dimana selama 5 (lima) tahun terakhir, ongkos naik hajinya selalu tetap sebesar RM9.980, tidak berfluktuasi, bahkan jika dikurskan ke dalam rupiah $^{38}$, rata-rata ongkos naik haji Malaysia lebih murah daripada Indonesia. Berikut data perbandingan biaya penyelenggaraan haji Indonesia dengan Malaysia dalam 5 (lima) tahun terakhir:

\footnotetext{
${ }^{37}$ Pemerintah Republik Indonesia, Pasal 24 huruf (a) dan (b), UU PKH.

${ }^{38}$ Kurs Transaksi Bank Indonesia, http://www.bi.go.id, diakses pada tanggal 17 Januari 2018.
} 


\begin{tabular}{|c|c|c|c|}
\hline \multirow{2}{*}{ No } & \multirow{2}{*}{ Tahun } & \multicolumn{2}{|c|}{$\begin{array}{c}\text { Biaya Penyelenggaran } \\
\text { Haji } \\
\text { (Setoran Jemaah) }\end{array}$} \\
\cline { 3 - 4 } & & $\begin{array}{c}\text { Indonesia }^{39} \\
\text { (Rp) }\end{array}$ & $\begin{array}{c}\text { Malaysia }^{40} \\
\text { (Rp) }\end{array}$ \\
\hline 1 & 2013 & 34.332 .456 & $32.466 .337,2$ \\
\hline 2 & 2014 & $36.985 .028,5$ & $35.828 .499,4$ \\
\hline 3 & 2015 & 34.581 .794 & $36.441 .670,6$ \\
\hline 4 & 2016 & 34.127 .046 & $32.924 .219,6$ \\
\hline 5 & 2017 & 34.306 .780 & $30.652 .372,4$ \\
\hline
\end{tabular}

Tabel 2: Ongkos Naik Haji Indonesia dan Malaysia Tahun 2013 Sampai Dengan Tahun 2017

Perbandingan tersebut di atas lebih terlihat dalam gambaran statistik berikut ini:

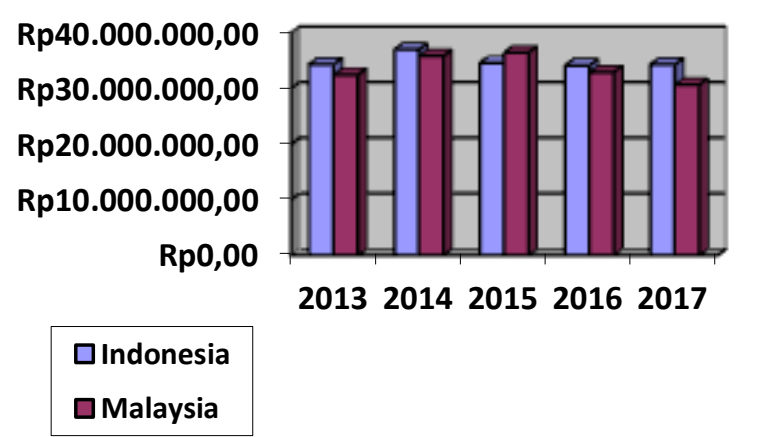

Gambar 1: Statistik Ongkos Naik Haji Indonesia dan Malaysia Tahun 2013 Sampai Dengan Tahun 2017

${ }^{39}$ Pemerintah Republik Indonesia, Peraturan Presiden RI Nomor 31 Tabun 2013 Tentang Biaya Penyelenggaraan Ibadah Haji Tabun 1434 H / 2013 M. Pemerintah Republik Indonesia, Peraturan Presiden RI Nomor 49 Tabun 2014 Tentang Biaya Penyelenggaraan Ibadah Haji Tabun 1435 H / 2014 M. Pemerintah Republik Indonesia, Peraturan Presiden RI Nomor 64 Tabun 2015 Tentang Biaya Penyelenggaraan Ibadah Haji Tabun 1436 H / 2015 M. Pemerintah Republik Indonesia, Keputusan Presiden RI Nomor 21 Tabun 2016 Tentang Biaya Penyelenggaraan Ibadab Haji Tabun 1437 H / 2016 M. Pemerintah Republik Indonesia, Keputusan Presiden RI Nomor 8 Tahun 2017 Tentang Biaya Penyelenggaraan Ibadah Haji Tabun 1438 H / 2017 M.

$$
{ }^{40} \text { Bayaran Haji Per Jemaah, }
$$

https://www.tabunghaji.gov.my, diakses pada tanggal 17 Januari 2018.
Berdasarkan hitungan statistik di atas, ternyata dalam waktu 5 (lima) tahun terakhir, hanya pada tahun 2015, ongkos naik haji Malaysia lebih mahal daripada Indonesia, sedangkan pada tahun 2013, 2014, 2016, dan 2017, ongkos naik haji Malaysia lebih murah daripada Indonesia.

Pengelolaan dana haji di Malaysia berbeda dengan Indonesia. Malaysia telah mengelola dana haji dengan pendekatan bisnis sejak tahun 1963 melalui lembaga Tabung Haji. Dalam mengembangkan dana tabungan haji, Tabung Haji Malaysia memiliki saham di Bank Islam Malaysia serta ikut berinvestasi di bidang teknologi, perkebunan, real estate, konstruksi, dan pasar modal. ${ }^{41}$

Hasil investasi dana tabungan haji digunakan untuk mensubsidi ongkos haji agar lebih murah dan sesuai dengan standar $\mathrm{ONH}$ Plus. Oleh karena itu, sebagaimana data di atas, dalam kurun waktu 5(lima) tahun terakhir ongkos naik haji Malaysia tetap sebesar RM9.980, selain itu, para calon jemaah haji juga mendapatkan imbal hasil berupa pelayanan haji yang berkualitas, di antaranya sebagai berikut: ${ }^{42}$

1. Memberikan bimbingan persiapan haji selama 6 (enam) bulan atau 15 (lima belas) kali pertemuan, bahkan setelah mengikuti manasik, para calon jemaah haji juga diwajibkan mengikuti ujian, jika masih ada yang belum lulus, maka akan diadakan manasik tambahan;

2. Menyewakan pemondokan yang lebih nyaman dan dekat dengan Masjidil Haram;

3. Mendirikan rumah sakit di Makkah dan Madinah serta pusat kesehatan di Arafah dan Mina;

${ }^{41}$ Detik, Begini Pengelolaan Dana Haji di Malaysia, m.detik.com, diakses pada tanggal 10 Januari 2018.

${ }^{42}$ Detik, Begini Pengelolaan Dana Haji di Malaysia, diakses pada tanggal 10 Januari 2018. Lihat juga, Triono Wahyu Sudibyo, Membandingkan Servis Jemaah Haji RI, Malaysia, dan Bangladesh, https://m.detik.com, diakses pada tanggal 17 Januari 2018. 
4. Melarang sebagian petugasnya turut melaksanakan ibadah haji; dan

5. Mengelola pengaturan pesawat udara, akomodasi, keamanan, dan jaminan kesehatan.

\section{KESIMPULAN}

Berdasarkan uraian di atas, persoalan formulasi akad pengelolaan dana haji di Indonesia masih dalam polemik dan perlu didudukkan secara bersama serta kajian yang mendalam untuk menentukan formulasi akad yang tepat. Sebagaimana telah diuraikan, setoran BPIH adalah dana yang dititipkan oleh calon jemaah haji kepada pemerintah (Kementerian Agama atau $\mathrm{BPKH}$ ) untuk membiayai penyelenggaraan ibadah haji mereka. Ketika dana tersebut dikelola oleh pemerintah, maka timbul persoalan tentang formulasi akad yang tepat untuk digunakan, apakah akad wakalah, mudlarabah (bagi hasil), atau sama sekali tidak lagi membutuhkan akad, pemerintah bertindak sebagai kuasa menurut undang-undang bagi para calon jemaah haji, sebagaimana pertimbangan putusan Mahkamah Konstitusi (MK).

Perdebatan dalam pengelolaan dana haji juga termasuk tentang objek tujuan investasi.
UU PKH hanya menentukan bahwa keuangan haji dapat diinvestasikan dan/atau ditempatkan pada produk perbankan, surat berharga, emas, investasi langsung dan investasi lainnya. Persoalannya adalah apakah objek investasi langsung dan investasi lainnya hanya sebatas bidang-bidang yang berkaitan dengan pelaksanaan ibadah haji dan kemaslahatan umat Islam secara umum atau juga dapat dimaknai sebagai objek investasi yang bersifat umum, seperti investasi di bidang infrastruktur.

Para calon jemaah haji sebagai pemilik dana BPIH, termasuk dana atau asset lain yang terbentuk dari dana tersebut, memiliki hak untuk mendapatkan perlindungan hukum. Oleh karena itu, dalam pengelolaan dana haji para calon jemaah haji berhak untuk mendapat kejelasan tentang imbal hasil yang akan diperoleh oleh para calon jemaah haji, sebagai pemilik dana dan kejelasan tentang konsep penyelesaian sengketa, jika terjadi perselisihan dalam pengelolaan dana tersebut. Meskipun dana haji memiliki nilai ekonomis yang sangat tinggi dan semestinya dia dikelola berdasarkan prinsip syariah. 


\section{DAFTAR KEPUSTAKAAN}

Aan Satori, Djam'an dan Komariyah, Metodologi Penulisan Kualitatif. (Bandung: Alfabeta, 2009).

Ahmad Muntaha A.M., Hukum Investasi Dana Haji, aswajamuda.com, diakses pada tanggal 07 Januari 2018.

Bayaran Haji Per Jemaah, https://www.tabunghaji.gov.my, diakses pada tanggal 17 Januari 2018.

Detik, Begini Pengelolaan Dana Haji di Malaysia, diakses pada tanggal 10 Januari 2018. Lihat juga, Triono Wahyu Sudibyo, Membandingkan Servis Jemaah Haji RI, Malaysia, dan Bangladesh, https://m.detik.com, diakses pada tanggal 17 Januari 2018.

Dewan Syariah Nasional Majelis Ulama Indonesia, Fatwa Dewan Syariah Nasional Majelis Ulama Indonesia (DSN-MUI) Nomor 20/DSN-MUI/IV/2001 Tentang Pedoman Pelaksanaan Investasi Untuk Reksadana.

Dewan Syariah Nasional Majelis Ulama Indonesia, Fatwa Dewan Syariah Nasional Majelis Ulama Indonesia (DSN-MUI) Nomor 03/DSN-MUI/IV/2000 Tentang Deposito.

Humas Sekretariat Kabinet Republik Indonesia, Jumlabnya Mendekati 100 Triliun, Menag: Seluruh Dana Haji Akan Diserabkan Pada BPKH, http://setkab.go.id, diakses pada tanggal 18 Januari 2018.

Ihsanudin, Jokowi Ingin Dana Haji Diinvestasikan Untuk Infrastruktur, https://kompas.com, diakses pada tanggal 15 Januari 2018.

Kementerian Agama, Keputusan Menteri Agama Nomor 20 Tahun 2008 Tentang Penetapan Kuota Haji Tabun $1429 \mathrm{H}$.

Kementerian Agama, Keputusan Menteri Agama Nomor 210 Tahun 2016 Tentang Penetapan Kuota Haji Tabun $1437 \mathrm{H} / 2017 \mathrm{M}$.

Kementerian Agama, Keputusan Menteri Agama Nomor 29 Tahun 2011 Tentang Penetapan Kuota Haji Tabun $1432 \mathrm{H}$.

Kementerian Agama, Keputusan Menteri Agama Nomor 46 Tabun 2009 Tentang Penetapan Kuota Haji Tabun $1430 \mathrm{H}$.

Kementerian Agama, Keputusan Menteri Agama Nomor 58 Tabun 2013 Tentang Penetapan Kuota Haji Tahun 1434 H / 2013 M.

Kementerian Agama, Keputusan Menteri Agama Nomor 64 Tabun 2014 Tentang Penetapan Kuota Haji Tabun 1435 H / 2014 M.

Kementerian Agama, Keputusan Menteri Agama Nomor 75 Tahun 2017 Tentang Penetapan Kuota Haji Tabun 1438 H / 2017 M.

Kementerian Agama, Laporan Keuangan Haji Tabun 2011 Sampai Dengan Tabun 2015.

Kementerian Agama, Peraturan Menteri Agama Nomor 23 Tabun 2011 Tentang Pengelolaan Biaya Penyelenggaraan Ibadah Haji.

Kitab Undang-Undang Hukum Perdata.

Kurs Transaksi Bank Indonesia, http://www.bi.go.id, diakses pada tanggal 17 Januari 2018.

M. Atho Mudzhar, Esai-Esai Sejarah Sosial Hukum Islam, (Yogyakarta: Pustaka Pelajar, 2014), Cet. Ke-1,

Mahkamah Agung RI, Peraturan Mabkamah Agung RI Nomor 2 Tabun 2008 Tentang ompilasi Hukum Ekonomi Syariah.

Mahkamah Konstitusi, Putusan Nomor 12/PUU-XIII/2015,

Mahkamah Konstitusi, Putusan Nomor 51/PUU-XV/2017,

Majelis Ulama Indonesia, Hasil Ijtima' Ulama IV Masail Fighiyah Mu'ashirah (Masalah Fiqh Kontemporer) Komisi B-2, tabun 2012.

Otoritas Jasa Keuangan (OJK), Peraturan OJK Nomor 69 /POJK.05/2016 Tentang Penyelenggaraan Usaha Perusahaan Asuransi, Perusahaan Asuransi Syariah, Perusabaan Reasuransi, Dan Perusahaan Reasuransi Syariah.

Pemerintah Republik Indonesia, Keputusan Presiden (Kepres) Nomor 22 Tahun 2001.

Pemerintah Republik Indonesia, Keputusan Presiden RI Nomor 21 Tahun 2016 Tentang Biaya Penyelenggaraan Ibadah Haji Tahun 1437 H / 2016 M. 
Pemerintah Republik Indonesia, Keputusan Presiden RI Nomor 8 Tabun 2017 Tentang Biaya Penyelenggaraan Ibadah Haji Tabun 1438 H / 2017 M.

Pemerintah Republik Indonesia, Peraturan Presiden RI Nomor 31 Tabun 2013 Tentang Biaya Penyelenggaraan Ibadah Haji Tabun 1434 H / 2013 M.

Pemerintah Republik Indonesia, Peraturan Presiden RI Nomor 49 Tabun 2014 Tentang Biaya Penyelenggaraan Ibadah Haji Tabun 1435 H / 2014 M.

Pemerintah Republik Indonesia, Peraturan Presiden RI Nomor 64 Tabun 2015 Tentang Biaya Penyelenggaraan Ibadah Haji Tabun 1436 H / 2015 M.

Pemerintah Republik Indonesia, Undang-Undang No.34 tahun 2014 tentang Pengelolaan Kenangan Haji

Pemerintah Republik Indonesia, Undang-Undang Nomor 19 Tahun 2008 Tentang Surat Berharga Syariah Negara.

Ridawan Khairandy, Hukum Kontrak Indonesia (Dalam Perspektif Perbandingan), (Yogyakarta: FH UII Press, 2013),

Riko Nazri, Optimalisasi Pengelolaan Dana Haji Untuk Kesejabteraan Jamaah Haji Indonesia (Sebuah Gagasan), (jurnal Khazanah, FIAI UII, vol. 6, no. 1 Juni 2013).

Siaran Pers Bersama Kemkominfo, Kemenag, Kementerian PPN/Bappenas, dan MUI, Manfaat Investasi Dana Haji Untuk. Umat, Forum Merdeka Barat 9, 05 Agustus 2017.

Undang-Undang Nomor 13 Tabun 2008 Tentang Penyelenggaraan Ibadah Haji.

Unnes Stock Exchange Study Forum (UNNSAF), Private Placement, https://unssaf.or.id, diakses pada tanggal 15 Januari 2018. 